\title{
Research on the Evaluation System of Economic Development Environment Based on the Factor Analysis Method
}

\author{
Nan-nan Zhang ${ }^{12}$ \\ ${ }^{1}$ Commercial College ,Agricultural University of Hebei, Baoding, China \\ ${ }^{2}$ Financial section of Central Institute for Correctional Police, Baoding, 071000, China
}

Keywords: economic development environment, factor analysis method; evaluation system

\begin{abstract}
Coordinated environment of economic development will provide power for economic development. Otherwise, it would counteract the development of economy. Aiming at this problem, using the factor analysis method and taking Chinese city for example, this article selects the 18 indexes of 36 cities throughout the country as the research object. Through calculation and analysis of the regional statistics, it is concluded that the economic operation, infrastructure, and environmental science and education are three public factors. On the basis of factor score and statistical data in past years, the paper evaluated the environment of economic development comprehensively.
\end{abstract}

\section{Introduction}

Study on environmental problems in economic development in our country is late, so it leads to drawbacks in many aspects of research. At present, on the economic development environment research, it mainly concentrated in evaluation of a regional economic development environment using linear weighted method through establishing the environmental evaluation indicator system. The result of study is the regional economic development environment score value. It is lack of detailed analysis of the economic development environment. Therefore, it is not conducive to deeply analyze the problems existing in the economic development environment and provide convenience for policy makers. In addition, from the point of view of dynamic development, the development of the region's economic environment is a dynamic process. Therefore, research on present situation of regional economic development environment and analysis of advantages and disadvantages existing in the regional economic development environment are key problems in the study of urban coordinated development.

\section{Factor Analysis Method}

\subsection{Characteristics of the factor variables}

The basic starting point of factor analysis method is turning many original variables into fewer common factors that could reflect the most information of original indexes and there is no correlation between the comprehensive indexes.

The characteristics of the factor variables are as follows.

(1)The number is far less than the number of original variables, but can reflect the most variance of the original variables.

(2) Variables are not related

(3) Factor variables are reconstruction of original variables

\subsection{Basic steps of factor analysis}

The basic steps of factor analysis are shown in figure 1 . 


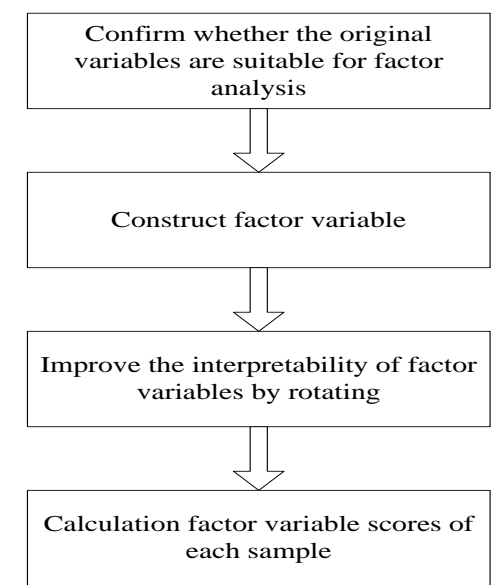

Fig.1 The basic steps of factor analysis

\subsection{Mathematical model of factor analysis}

Common factors in factor analysis method are not direct observation but objective existence of common influence factor. Each variable can be expressed as the sum of linear function of public factor and special factor

$$
X_{\mathrm{i}}=\mathrm{a}_{\mathrm{i} 1} \mathrm{~F}_{1}+\mathrm{a}_{\mathrm{i} 2} \mathrm{~F}_{2}+\ldots+\mathrm{a}_{\mathrm{im}} \mathrm{F}_{\mathrm{m}}+\varepsilon_{\mathrm{i}}, \quad(\mathrm{i}=1,2, \cdots, \mathrm{p})
$$

This model adopts a matrix-form expression: $\mathrm{X}=\mathrm{AF}+\varepsilon$

$$
X=\left[\begin{array}{c}
X_{1} \\
X_{2} \\
\vdots \\
X_{p}
\end{array}\right], A=\left[\begin{array}{cccc}
a_{11} & a_{12} & \cdots & a_{1 m} \\
a_{21} & a_{22} & \cdots & a_{2 m} \\
\cdots & \cdots & \cdots & \cdots \\
a_{p 1} & a_{p 2} & \cdots & a_{p m}
\end{array}\right], F=\left[\begin{array}{c}
F_{1} \\
F_{2} \\
\vdots \\
F_{m}
\end{array}\right], \varepsilon=\left[\begin{array}{c}
\varepsilon_{1} \\
\varepsilon_{2} \\
\vdots \\
\varepsilon_{p}
\end{array}\right]
$$

\section{Establish index system}

According to actual requirement, taking Chinese city for example, this paper selects 36 cities throughout the country as the research object and chooses 18 major economic indicators to build the evaluation system. Cities are mainly provincial capitals and economic indicators are the comprehensive indexes in China Statistical Yearbook. As shown in Table 1 below.

Table1 Environment evaluation index system of urban economic development

\begin{tabular}{c|c|c|c}
\hline Number & Indicator & Number & Indicator \\
\hline 1 & annual total population & 10 & number of telephone subscribers \\
2 & GDP & 11 & social total retail sales \\
3 & passenger traffic & 12 & Indicator \\
\hline Number & Indicator & Number & number of bus \\
\hline 4 & education investment & 13 & number of theater and cinema \\
5 & financial budget income & 14 & scientific research and technical \\
6 & fixed assets investments & 15 & workers \\
7 & resident's savings deposit & 16 & number of students in colleges \\
8 & average salary & 17 & number of hospital \\
9 & number of post office & 18 & industrial waste emissions \\
\hline
\end{tabular}

\section{Evaluation and analysis of economic development}

Before using the factor analysis model analysis indicators evaluation system, the data must be 
standardized. Then put the standardized data into the economic development environment model. This paper uses SPSS17.0 to the index system of urban development and environment factor analysis. The specific calculation steps are as follows.

Table 2 The variance contribution rate of common factor

\begin{tabular}{|c|c|c|c|c|c|c|c|c|c|}
\hline \multirow[b]{2}{*}{$\begin{array}{c}\text { Compositio } \\
\mathrm{n}\end{array}$} & \multicolumn{3}{|c|}{ Initial eigenvalue } & \multicolumn{3}{|c|}{\begin{tabular}{|c|}
$\begin{array}{c}\text { Extraction of sum of squares } \\
\text { loaded }\end{array}$ \\
\end{tabular}} & \multicolumn{3}{|c|}{$\begin{array}{c}\text { Rotate the sum of squares } \\
\text { loaded }\end{array}$} \\
\hline & Total & $\begin{array}{c}\text { Variance } \\
\text { ontributio } \\
\text { n rate }\end{array}$ & $\begin{array}{c}\text { cumulative } \\
\text { contributio } \\
\text { n rate }\end{array}$ & Total & $\begin{array}{c}\text { Variance } \\
\text { contributio } \\
\text { n rate }\end{array}$ & $\begin{array}{c}\text { Cumulativ } \\
\text { e } \\
\text { contributio } \\
\text { n rate }\end{array}$ & Total & $\begin{array}{c}\text { Variance } \\
\text { contributio } \\
\text { n rate }\end{array}$ & $\begin{array}{c}\text { Cumulativ } \\
\text { e } \\
\text { contributio } \\
\text { n rate }\end{array}$ \\
\hline 1 & $\begin{array}{c}10.79 \\
5\end{array}$ & 59.973 & 59.973 & $\begin{array}{c}10.79 \\
5\end{array}$ & 59.973 & 59.973 & $\begin{array}{c}6.64 \\
6\end{array}$ & 36.923 & 36.923 \\
\hline 2 & 2.604 & 14.466 & 74.439 & 2.604 & 14.466 & 74.439 & $\begin{array}{c}4.87 \\
3\end{array}$ & 27.073 & 63.996 \\
\hline 3 & 1.416 & 7.868 & 82.307 & 1.416 & 7.868 & 82.307 & $\begin{array}{c}3.29 \\
6\end{array}$ & 18.311 & 82.307 \\
\hline 4 & .882 & 4.900 & 87.207 & & & & & & \\
\hline 5 & .679 & 3.771 & 90.977 & & & & & & \\
\hline 6 & .577 & 3.208 & 94.186 & & & & & & \\
\hline 7 & .370 & 2.056 & 96.242 & & & & & & \\
\hline 8 & .218 & 1.213 & 97.455 & & & & & & \\
\hline 9 & .176 & .977 & 98.432 & & & & & & \\
\hline 10 & .091 & .503 & 98.936 & & & & & & \\
\hline 11 & .069 & .384 & 99.320 & & & & & & \\
\hline 12 & .044 & .246 & 99.566 & & & & & & \\
\hline 13 & .031 & .173 & 99.739 & & & & & & \\
\hline 14 & .017 & .097 & 99.836 & & & & & & \\
\hline 15 & .015 & .082 & 99.918 & & & & & & \\
\hline 16 & .007 & .039 & 99.956 & & & & & & \\
\hline 17 & .005 & .029 & 99.986 & & & & & & \\
\hline 18 & .003 & .014 & 100.000 & & & & & & \\
\hline
\end{tabular}

(1)Extract the common factor. Principal component analysis (PCA) is used and principal component is extracted under the constraints of eigenvalues greater than 1 . The variance contribution rate of common factor can be gained by calculation. It is shown in table 2. As can be seen from the table in the extraction of three common factors, cumulative contribution rate of these three common factors is $82.307 \%$, which is meet the requirements of the principle of statistics is greater than $80 \%$. It means that the extracted common factors have a good ability to explain the original information.

(2) Factor rotation. In order to make the extraction of various factors have the ability to better explain the original information, thus it rotates the three common factors. Maximum balance method is used in this paper and the result of it is shown in table 3. Can be seen from the table in the main cities in China development environment evaluation index system contains 18 indicators, after statistical analysis can extract the three common factors. 
Table 3 Factor rotation results analysis

\begin{tabular}{|c|c|c|c|}
\hline \multirow{2}{*}{$\begin{array}{l}\text { Economic development environmental } \\
\text { indicators }\end{array}$} & \multicolumn{3}{|c|}{ Common factor } \\
\hline & 1 & 2 & 3 \\
\hline GDP & 0.760 & & \\
\hline financial budget income & 0.703 & & \\
\hline resident's savings deposit & 0.812 & & \\
\hline average salary & 0.738 & & \\
\hline social total retail sales & 0.742 & & \\
\hline number of telephone subscribers & 0.79 & & \\
\hline total exports & 0.936 & & \\
\hline number of bus & 0.880 & & \\
\hline passenger traffic & 0.603 & & \\
\hline fixed assets investments & 0.859 & & \\
\hline annual total population & & 0.903 & \\
\hline number of post office & & 0.885 & \\
\hline number of theater and cinema & & 0.716 & \\
\hline number of hospital & & 0.922 & \\
\hline education investment & & & 0.638 \\
\hline $\begin{array}{l}\text { scientific research and technical } \\
\text { workers }\end{array}$ & & & 0.713 \\
\hline number of students in colleges & & & 0.776 \\
\hline industrial waste emissions & & & 0.651 \\
\hline
\end{tabular}

Table 4 Economy development environment evaluation results of 36 cities in China

\begin{tabular}{|c|c|c|c|c|c|c|c|c|c|}
\hline $\begin{array}{c}\text { Ranki } \\
\text { ng }\end{array}$ & Factor 1 & Fac & r 3 & $\begin{array}{l}\text { Composi } \\
\text { te scores }\end{array}$ & $\begin{array}{c}\text { Ranki } \\
\text { ng }\end{array}$ & Fac & 2 & $\mathrm{Fa}$ & $\begin{array}{c}\text { Composite } \\
\text { scores }\end{array}$ \\
\hline 1 & Beijing & $\begin{array}{c}\text { Chongqin } \\
\mathrm{g}\end{array}$ & $\begin{array}{c}\text { Guangzho } \\
\mathrm{u}\end{array}$ & Bei & 19 & in & & & $\begin{array}{c}\text { Shijiazhua } \\
\text { ng }\end{array}$ \\
\hline 2 & $\begin{array}{c}\text { Shenzhe } \\
n\end{array}$ & Chengdu & Shanghai & Shanghai & 20 & Wuhan & in & Ningbo & Jinan \\
\hline 3 & Shang & נוביד T & han & $\begin{array}{c}\text { Chongqi } \\
\text { ng }\end{array}$ & 21 & Cha & $\mathrm{Ku}$ & ng & Hefei \\
\hline 4 & $\begin{array}{c}\text { Guangzh } \\
\text { ou }\end{array}$ & Shanghai & Hangzhou & $\begin{array}{c}\text { Shenzhe } \\
n\end{array}$ & 22 & $\begin{array}{c}\text { Changchu } \\
n\end{array}$ & & & Fuzhou \\
\hline 5 & Tian & Beijing & Nanj & $\begin{array}{c}\text { Guangzh } \\
\text { ou }\end{array}$ & 23 & Hai & Nir & Hefei & $\begin{array}{c}\text { Changchu } \\
n\end{array}$ \\
\hline 6 & Nin & She & Ying & Tia & 4 & $X$ & & $\begin{array}{c}\text { Changch } \\
\text { un }\end{array}$ & Kun \\
\hline 7 & $\begin{array}{c}\text { Hangzho } \\
\mathrm{u}\end{array}$ & Harbin & $\begin{array}{c}\text { Shijiazhua } \\
\text { ng }\end{array}$ & Chengdu & 25 & Kunn & $\begin{array}{c}\text { Nanchan } \\
\text { g }\end{array}$ & $\mathrm{Ta}$ & Taiyuan \\
\hline 8 & Nanji & $\begin{array}{c}\text { Zhengzho } \\
\mathrm{u}\end{array}$ & Jinan & $\begin{array}{c}\text { Hangzho } \\
\mathrm{u}\end{array}$ & 2 & $X$ & $\begin{array}{c}\text { Hangzho } \\
\mathrm{u}\end{array}$ & & ng \\
\hline 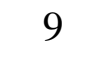 & Qingdao & Hefei & Dalian & Wuhan & 27 & Tai & Nanjing & bu & Xia \\
\hline 10 & & $\mathrm{X}$ & $\begin{array}{c}\text { Zhengzho } \\
\text { u }\end{array}$ & Nanjing & 28 & EI & hou & hou & Nanchang \\
\hline 11 & 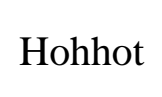 & $\begin{array}{c}\text { Shijiazhua } \\
\text { ng }\end{array}$ & Tianjin & $\mathrm{Nir}$ & רo & Lan & qi & hot & Guiy \\
\hline 12 & Xiamen & Shenyang & Chengdu & & 30 & Jinan & Haikou & Guiyang & Hohhot \\
\hline 13 & $\begin{array}{c}\text { Shenyan } \\
\text { g }\end{array}$ & Qingdao & $\begin{array}{c}\text { Chongqin } \\
\text { g }\end{array}$ & $\begin{array}{c}\text { Shenyan } \\
\text { g }\end{array}$ & 31 & Guiyang & ng & Urumqi & Urumqi \\
\hline
\end{tabular}




\begin{tabular}{|c|c|c|c|c|c|c|c|c|c|}
\hline 14 & Chengdu & Cha & Char & Qing & 32 & $\begin{array}{c}\text { Zhengzho } \\
\mathrm{u}\end{array}$ & $\begin{array}{c}\text { Yinchua } \\
n\end{array}$ & $\begin{array}{c}\text { Yinchua } \\
n\end{array}$ & $\mathrm{I}=$ \\
\hline 15 & Dali & $\begin{array}{c}\text { Changchu } \\
n\end{array}$ & & Dal & 3 & Nanchang & Xiamen & Xining & \\
\hline & Fuz & Guiyang & Nan & & 34 & & Ho & Lhasa & \\
\hline 17 & $\begin{array}{c}\text { Yinchua } \\
n\end{array}$ & 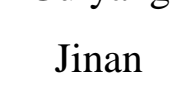 & & $\begin{array}{r}\text { Zher } \\
\text { o }\end{array}$ & 2 & $\begin{array}{c}\text { Chongqin } \\
\mathrm{g}\end{array}$ & Lh & $\mathrm{Ha}$ & \\
\hline 18 & U Uru & & & $\begin{array}{c}\text { Changsh } \\
\mathrm{a} \\
\end{array}$ & 36 & $\begin{array}{c}\text { Shijiazhua } \\
\text { ng }\end{array}$ & $\begin{array}{c}\text { Guangzh } \\
\text { ou }\end{array}$ & $\begin{array}{c}\text { Shenzhe } \\
n\end{array}$ & g \\
\hline
\end{tabular}

(3) Evaluation result. The table 4 shows the single factor scores ranking and composite scores ranking respectively. There is economic operation factor ranking, infrastructure factor ranking, environmental science and education factor ranking and Composite scores ranking from left to right respectively.36 cities ranking on environment in every factor in economic development can be seen from the table, as well as the city's economic development overall situation comprehensive ranking.

\section{Conclusion}

This paper has shown that there is a clear imbalance in the development of major cities in China. Beijing, Shanghai, Guangzhou, and other coastal cities' economic development environment are in a relatively leading level. The central and western regions are relatively poor. To such a situation, on one hand, we can adopt horizontal and mutual assistance to know the shortage of development environment by learning other urban development experience. On the other hand, it must put efforts to use its own advantages factors driving the disadvantage factors and realize the comprehensive coordinated development.

\section{References}

[1]Ran Lun, Li Jinlin.The application of factor analysis in the evaluation of comprehensive performance of listed companies on the small and medium sized enterprises board [J], Mathematical statistics and management, 2005 (1):75-79.

[2]Cao Hongjun, Pang Dunzhi. Research on index system of regional economic development environment [J]. Journal of ocean university of China (Social science edition) , 2006 (3) : 21-24.

[3] Dunford M. Theorizing regional economic performance and the changing territorial division of labor[J]. Regional Studies, Cambridge,2003,37(8): 835-839.

[4]Niu Panqiang, Xie Fuji. Empirical study on relationship between regional economic development environment and economic development [J].Technology economics, 2008, 27 (1) : 13-17.

[5]Fan Decheng,Wang Xiaohui.The research on evaluation index system and evaluat on method of regional industrial investment environment [J].Science \& Technology Progess and Policy, 2009, 26 (14) : 118-120.

[6]Guan Hua, Li Jinxia, He Jun. Study on Hebei province regional economies competitive power evaluation based on factor analysis [J]. Economy and Management, 2010, 24 (10) : 78-80.

[7] Yu Ting. Investment environment evaluation and analysis of major cities in central China [J].Journal of Industrial Technology Economics, 2010，29 (3) :26-31.

[8]Bo Zhang, Xianjin Huang. Researches and empirical evaluation index system of circular economy development [J]. Chinese Journal of Population Resources and Environment, 2005, 15(3): 22-25. 
[9]Jun Ma, Lin Zhou, Wei Li. Build urban low-carbon economy evaluation index system taking low carbon development present situation of six cities in the eastern coastal provinces as the example [J]. Science \& Technology Progress and Polic, 2010, 27(22): 165-167.

[10]Taiyang Zhong, Xianjin Huang, Lulu Li. Regional circular economy assessment: method, index system and empirical research [J].Resources Science, 2006, 28(2): 154-162. 